\title{
Linking biogenic hydrocarbons to biogenic aerosol in the Borneo rainforest
}

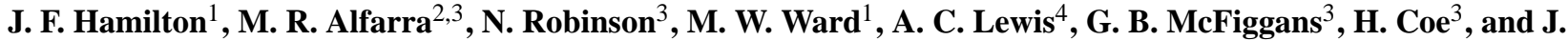 \\ D. Allan ${ }^{2,3}$ \\ ${ }^{1}$ Department of Chemistry, University of York, Heslington, York, YO10 5DD, UK \\ ${ }^{2}$ National Centre for Atmospheric Science (NCAS), School of Earth, Atmospheric and Environmental Sciences, University of \\ Manchester, Manchester, M13 9PL, UK \\ ${ }^{3}$ Centre for Atmospheric Science, School of Earth, Atmospheric and Environmental Sciences, University of Manchester, \\ Manchester, M13 9PL, UK \\ ${ }^{4}$ National Centre for Atmospheric Science, University of York, Heslington, York, YO10 5DD, UK
}

Correspondence to: J. F. Hamilton (jacqui.hamilton@york.ac.uk)

Received: 29 May 2013 - Published in Atmos. Chem. Phys. Discuss.: 8 July 2013

Revised: 3 October 2013 - Accepted: 21 October 2013 - Published: 21 November 2013

\begin{abstract}
Emissions of biogenic volatile organic compounds are though to contribute significantly to secondary organic aerosol formation in the tropics, but understanding these transformation processes has proved difficult, due to the complexity of the chemistry involved and very low concentrations. Aerosols from above a Southeast Asian tropical rainforest in Borneo were characterised using liquid chromatography-ion trap mass spectrometry, high-resolution aerosol mass spectrometry and Fourier transform ion cyclotron resonance mass spectrometry (FTICRMS) techniques. Oxygenated compounds were identified in ambient organic aerosol that could be directly traced back to isoprene, monoterpenes and sesquiterpene emissions, by combining field data on chemical structures with mass spectral data generated from synthetically produced products created in a simulation chamber. Eighteen oxygenated species of biogenic origin were identified in the rainforest aerosol from the precursors isoprene, $\alpha$-pinene, limonene, $\alpha$-terpinene and $\beta$ caryophyllene. The observations provide the unambiguous field detection of monoterpene and sesquiterpene oxidation products in SOA above a pristine tropical rainforest. The presence of 2-methyl tetrol organosulfates and an associated sulfated dimer provides direct evidence that isoprene in the presence of sulfate aerosol can make a contribution to biogenic organic aerosol above tropical forests. High-resolution mass spectrometry indicates that sulfur can also be incorpo-
\end{abstract}

rated into oxidation products arising from monoterpene precursors in tropical aerosol.

\section{Introduction}

Tropical and equatorial forests account for over half of the world's forests and play a crucial role in climate regulation, through their interaction with solar radiation and hydrological cycle, and as a source of precursors of cloud condensation nuclei. Globally, tropical forests are estimated to emit $\sim 500 \mathrm{Tg} \mathrm{Cyr}^{-1}$ as biogenic volatile organic compounds (BVOC) to the atmosphere, half of the global BVOC emission (Guenther et al., 1995, 2006: global total $\left.1150 \mathrm{Tg} \mathrm{yr}^{-1}\right)$. Atmospheric oxidation of BVOCs by the hydroxyl radical, ozone and nitrate radical leads to the formation of more oxidised compounds, which can lead to the formation of secondary organic aerosol (SOA). The majority of studies of organic aerosol composition in forested regions have taken place in boreal (Kristensen and Glasius, 2011; Kallio et al., 2006) and temperate forests (Gomez-Gonzalez et al., 2012; Surratt et al., 2007; Wang et al., 2008) of the Northern Hemisphere. The tree species found in tropical rainforests are very different, being dominated by lowland evergreen broadleaf rainforest. There are relatively limited reported studies of the interaction between tropical forests and atmospheric chemistry, with the majority of these studies taking place in Amazonia (Martin et al., 2010; Andreae 
et al., 2002), a small number in Africa (Capes et al., 2009; Redelsperger et al., 2006) and very little in Southeast Asia. The rainforest of Amazonia is a large inland forest, whereas SE Asia is a complex series of islands, with rainforests that are in much closer proximity to the maritime environment. Predictably the architecture and taxonomy of trees are also different, with SE Asian forest being dominated by the family Dipterocarpaceae (Whitmore, 1984).

The multinational OP3 (Oxidant and Particle Photochemical Processes above a south-east Asian tropical rainforest) project and the ACES (Aerosol Coupling in the Earths System) project had the aim of better understanding the complex links between the biosphere, atmospheric composition and climate (Hewitt et al., 2010). Two highly instrumented, intensive measurement campaigns were carried out at the Global Atmospheric Watch station, in Danum Valley, Sabah, Borneo. This is situated within a region that was selectively timber harvested in 1988 (Tangki and Chappell, 2008) and is around $5 \mathrm{~km}$ from the protected forest area known as the Danum Valley Conservation Area (DVCA). Measurements of BVOCs taken as part of the OP3 project indicated that the dominant BVOC species observed was isoprene, with an average ground level mixing ratio of around $1 \mathrm{ppb}$ and a maximum value of $2.5 \mathrm{ppb}$ (Jones et al., 2011). Speciated monoterpene mixing ratios were also measured at this location for the first time and indicated a monoterpene to isoprene ratio of around $0.3\left(\mathrm{ppb} \mathrm{ppb}^{-1}\right)$ during the day and 2.0 at night. The relative abundance of the individual monoterpenes generally increased in the order of $\alpha$-pinene $<\Delta$ 3 -carene $<$ camphene $<$ limonene $<\gamma$-terpinene. However, it is most likely there were many other lower concentration monoterpenes and sesquiterpenes present that were not analysed using the GC-FID technique of Jones et al. (2011).

Even when aerosol measurements have been made, surprisingly little is known about the composition of BSOA in tropical forests due to the generally low levels of OA encountered and the highly complex chemical nature of the OA matrix. During the OP3 study presented here, Robinson et al. (2011a) used positive matrix factorization on highresolution aerosol mass spectrometer (HR-AMS) data and identified an AMS factor, $82 \mathrm{Fac}$, that was linked to isoprene oxidation products and which corresponded to an average of $23 \%\left(0.18 \mu \mathrm{g} \mathrm{m}^{-3}\right)$ and reaching as much as $53 \%$ $\left(0.50 \mu \mathrm{g} \mathrm{m}^{-3}\right)$ of the total organic loading. This AMS factor provided some insight into an active role for isoprene but without chemical structures made it impossible to determine the chemistry involved. Isoprene SOA tracer compounds 2-methyl tetrols have been measured in aerosol collected in a tropical rainforest, although they constituted a very small fraction of the total aerosol mass (Claeys et al., 2004). There remains rather limited knowledge of the mechanisms by which monoterpenes contribute to BSOA formation in tropical forests in contrast to a number of studies published on boreal locations; although monoterpenes may be present in much lower gas phase abundance here compared to isoprene, they may have significantly higher aerosol yields. During the day monoterpenes react with hydroxyl radicals and ozone and during the night with ozone and $\mathrm{NO}_{3}$ radicals to form oxidised reaction products. There have been many lab-based studies of these reactions and a large amount of information on their oxidation products is available in the published literature, but there is only very limited evidence of the occurrence of these in real-world ambient aerosol. Additionally in a tropical rainforest there are likely to be emissions of sesquiterpenes, which have also been implicated in new particle formation (Bonn and Moortgat, 2003).

This paper reports our investigation of the links between BSOA and a range of BVOC precursors, with the aim of better understanding organic aerosol formation in tropical rainforests. Using photochemical reaction chamber experiments, synthetic BSOA was initially produced from a series of biogenic precursors believed to be present in Danum Valley, based on previous taxonomic studies. These proxy-aerosols were used to generate representative organic chemical tracers and associated mass spectra of BSOA that could be linked to specific BVOCs precursors. The synthetic step has been essential, since most biogenic oxidation products are not commercially available. Aerosol samples were collected at the WMO Bukit Atur Global Atmospheric Watch station (GAW), Sabah, in Malaysian Borneo (4.981 $\left.{ }^{\circ} \mathrm{N}, 117.844^{\circ} \mathrm{E}\right)$ during June and July 2008 and analysed using off-line techniques, including liquid chromatography coupled to electrospray ionisation ion trap mass spectrometry $\left(\mathrm{LC}-\mathrm{MS}^{2}\right.$ ) and Fourier transform ion cyclotron resonance mass spectrometry (FTICRMS).

\section{Experimental}

\subsection{Offline aerosol analysis}

Particles less than $2.5 \mu \mathrm{m}$ were collected onto pre-fired $47 \mathrm{~mm}$ quartz filters using a Partisol Plus 2025 (Thermo) with a $\mathrm{PM}_{2.5}$ impactor. Twenty-four hour samples were collected at two locations from midnight to midnight local time. Eleven samples were collected between 28 June 2008 and 9 July 2008 at $10 \mathrm{~m}$ on a hill surrounded by forest, effectively at canopy top height at the Bukit Atur GAW station. An additional eleven samples were collected between the 12 July 2008 and 23 July 2008, at a site within the forest canopy at a height of $2 \mathrm{~m}$. Full details on the site locations can be found in (Hewitt et al., 2010). Filters were transported at sub zero temperatures and stored in a freezer at $-20^{\circ} \mathrm{C}$ until analysis. Approximately an area of $7 / 8$ th of the filter sample was extracted into high purity water, filtered and reduced to $1 \mathrm{~mL}$ using a vacuum solvent evaporator (Biotage, Sweden) and the remaining portion retained for other analysis. The water soluble compounds were analysed initially using liquid chromatography-ion trap mass spectrometry (LCMS/MS). Reversed phase LC separation was achieved using 


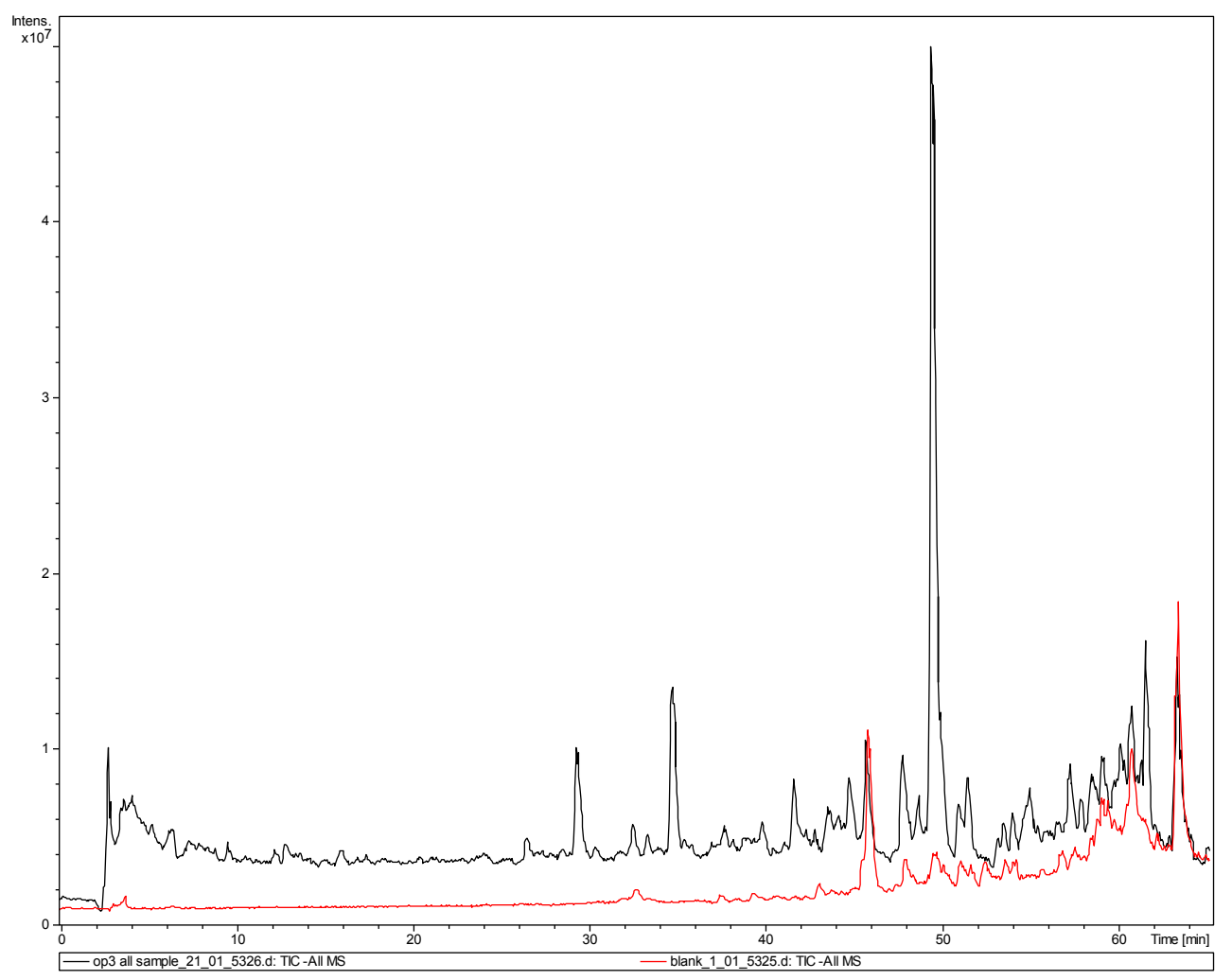

Fig. 1. Total ion chromatograms for LC-MS analysis in negative ionisation mode. Black: OP3_all extract from filters collected at the Bukit Atur, Borneo, site. Red: blank control sample. Many of the peaks after 45 minutes are contaminants from the methanol used in the LC analysis.

an HP 1100 LC system equipped with an Eclipse ODS-C 18 column with $5 \mu \mathrm{m}$ particle size (Agilent, $4.6 \mathrm{~mm} \times 150 \mathrm{~mm}$ ). Samples $(60 \mu \mathrm{l})$ were injected then eluted by gradient elution with solvents A; $0.1 \% \mathrm{v} / \mathrm{v}$ formic acid water (Optima grade, Fisher) and B: methanol (Optima grade, Fisher) and a gradient program of $3 \% \mathrm{~B}$ at time 0 min to $100 \% \mathrm{~B}$ at 60 minutes with a flow rate of $0.6 \mathrm{ml} \mathrm{min}{ }^{-1}$. Mass spectrometry analysis was performed using an HCT-Plus ion trap mass spectrometer with electrospray ionisation (Bruker Daltonics $\mathrm{GmbH}$ ). Electrospray ionisation (ESI) was carried out at $350^{\circ} \mathrm{C}$ with a nebuliser pressure of 4.82 bar and a nitrogen drying gas flow of $121 \mathrm{~min}^{-1}$. Two different separations were carried out for each sample, one with positive MS ionisation and one in negative ionisation, scanning from $\mathrm{m} / \mathrm{z}, 50-600$ and with automatic selection of the three most abundant ions for $\mathrm{MS}^{2}$ by collision induced dissociation (CID). Negative ionisation has been used as the primary means of identification of tracers since the positive ionisation mode resulted in the formation of sodium adducts, which generally produced few diagnostic ions when subjected to CID.

The detection limit of the LC-MS ${ }^{2}$ method was found to be rather high for the daily ambient samples and it was difficult to obtain product ion mass spectra. The instrument was thoroughly cleaned and subsequently optimised using a cis- pinonic acid standard ( $20 \mathrm{ppb}$ ) to improve the sensitivity. The remaining pieces of each filter left over from the other analysis were combined to give one high concentration extract for the entire campaign, labelled here as rainforest OA extract. This extract was redissolved in $200 \mu$ of solvent only, which was sufficient to carry out a LC-MS ${ }^{2}$ analysis in positive and negative ionisation mode and a direct infusion on the FTICRMS. The extract now shows many peaks and an increased baseline over the blank chromatogram, a result of the co-elution of many low concentration species, as shown in Fig. 1.

Samples were also analysed at high mass resolution using a Bruker APEX 9.4 T Fourier Transform Ion Cyclotron Resonance Mass Spectrometer. Extracts were sprayed at a flow rate of $2 \mu \mathrm{L} \mathrm{min}^{-1}$, into an Apollo II electrospray interface with ion funnelling technology. Spectra were acquired in both positive and negative ion mode over the scan range $\mathrm{m} / \mathrm{z}$ 100-3000 using the following MS parameters: nebulising gas flow: $0.9 \mathrm{~L} \mathrm{~min}^{-1}$; drying gas flow: $5 \mathrm{~L} \mathrm{~min}^{-1}$; drying temperature: $190^{\circ} \mathrm{C}$; collision cell accumulation: 0.05 $0.5 \mathrm{~s}$; and data acquisition size: $2 \mathrm{Mb}$ (yielding a target resolution of 130000 at $\mathrm{m} / \mathrm{z}$ 400). Data were analysed using DataAnalysis 4.0 software (Bruker Daltonics, Bremen, Germany). The instrument was calibrated using protonated 
(positive ion mode) or deprotonated (negative ion mode) arginine clusters. The mass spectra were internally recalibrated with a series of prominent peaks. Background contaminants also seen in pure water and blank extracted filters were identified.

The MS software uses a user defined set of conditions to determine the molecular formulae. In this case the following molecular configurations were allowed; unlimited numbers of $\mathrm{C}, \mathrm{H}$ and $\mathrm{O}, 0-3$ nitrogen and $0-1$ sulfur. Chemical formulae were assigned to the masses of singly charged ions $100<\mathrm{m} / z<600$ after internal recalibration using fatty acid signals and a maximum error of $10 \mathrm{ppm}$ for ions with a relative intensity of greater than $0.01 \%$. Isotopic ratios were used for further confirmation of the formulae. Background contaminant peaks also seen in pure water and blank extracted filters were manually removed from the analysis.

\subsection{Simulation chamber experiments}

Simulation chamber experiments were used to generate aerosols that could subsequently be used to aid in the identification of biogenic SOA tracer compounds. The Manchester aerosol chamber used for these experiments is a $18 \mathrm{~m}^{3}(3 \mathrm{~m}$ $(\mathrm{H}) \times 3 \mathrm{~m}(\mathrm{~L}) \times 2 \mathrm{~m}(\mathrm{~W}))$ FEP Teflon bag mounted on three rectangular aluminium frames. The air charge in the bag was dried and filtered for gaseous impurities and particles using a combination of Purafil, charcoal and HEPA filters, prior to humidification with ultrapure deionised water. Precursor VOCs were introduced into the chamber through injection into a heated glass bulb fed with a flow of high purity nitrogen. $\mathrm{NO}_{\mathrm{x}}$ levels were controlled by injection from a cylinder into the charge line and a high capacity $\mathrm{O}_{3}$ generator was employed to control initial $\mathrm{O}_{3}$ concentrations as well as serving as a cleaning agent during flushing between experiments. A series of halogen lamps and a $6 \mathrm{~kW}$ Xenon arc lamp were used to irradiate the chamber and initiate $\mathrm{OH}$ chemistry. Full details can be found in (Hamilton et al., 2011). Experiments were carried out at $25^{\circ} \mathrm{C}$ and nominal relative humidity of $50-70 \%$. A complete list of chamber experiments used to determine tracer compounds is shown in Table 1.

Filters were collected in a specially constructed holder, positioned in the chamber vent line. Aerosol samples were collected onto $47 \mathrm{~mm}$ quartz fibre filters (Whatman) at a flow rate of $3 \mathrm{~m}^{3} \mathrm{~min}^{-1}$. After sampling, filters were immediately placed in pre-cleaned glass vials and stored below $-20^{\circ} \mathrm{C}$ until analysis. Filters were analysed using the LC$\mathrm{MS}^{2}$ method above.

\section{Results}

A targeted analytical approach has been used to determine if terpenoid SOA is present in the aerosol, by comparing compositional data generated using LC-MS ${ }^{2}$ from the Borneo aerosol samples to synthetic SOA generated from biogenic VOCs. The BVOCs chosen for synthetic production in the chamber were based on knowledge gained from leaf cuvette measurements of the dominant tree species in a $300 \mathrm{~m}^{2}$ footprint of the GAW tower (S. Owen, personal communication, 2010) and represented a range of reactivities and functionalities. Seven chemical species were chosen, including isoprene, monoterpenes ( $\alpha$-pinene, limonene, myrcene, $\alpha$-terpinene), oxygenated monoterpene (linalool) and a sesquiterpene ( $\beta$-caryophyllene). Photo-oxidation experiments using approximately 50 and $250 \mathrm{ppb}$ initial BVOC precursor concentrations were carried out at the Manchester Aerosol Chamber for each species as shown in Table 1. For limonene and $\beta$-caryophyllene, filters were also collected at 2, 4 and $6 \mathrm{~h}$ to investigate the effect of ageing (Alfarra et al., 2012). Experiments were carried out at relatively high $\mathrm{NO}_{\mathrm{x}}$ levels $\left(\mathrm{VOC}: \mathrm{NO}_{\mathrm{x}} \sim 2\right.$ ) and so a direct comparison of the overall composition distribution between the chamber samples and the field samples (BVOC: $\mathrm{NO}_{\mathrm{x}} \sim 100$ ) is not possible. The higher $\mathrm{NO}_{\mathrm{x}}$ levels in the chamber will inevitably lead to some differences in the reaction mechanism. This has been seen in the case of isoprene where at low $\mathrm{NO}_{\mathrm{x}}$, $\mathrm{RO}_{2}+\mathrm{RO}_{2}$ and $\mathrm{RO}_{2}+\mathrm{HO}_{2}$ reactions dominate and at high $\mathrm{NO}_{\mathrm{x}}, \mathrm{RO}_{2}+\mathrm{NO}$ reactions dominate. However, towards the end of the experiment, when all $\mathrm{NO}$ has been converted to $\mathrm{NO}_{2} / \mathrm{NO}_{\mathrm{y}}$, any remaining $\mathrm{BVOC}$ will react with ozone and $\mathrm{OH}$ under more relevant conditions. Therefore, oxidation products formed under low $\mathrm{NO}_{\mathrm{x}}$ conditions should also be present and thus can act as tracers for a specific BSOA precursor in our field samples, despite the difference in $\mathrm{NO}_{\mathrm{x}}$ regimes.

The chamber filters were extracted into water and analysed using the same LC-MS ${ }^{2}$ method as the field filters. A large number of peaks were seen in each SOA sample. The addition of LC allows monoterpene oxidation product isomers, with the same $m / z$ but different structures to be separated. An example of this are the isomers with $\mathrm{MW}=168 \mathrm{Da}$, where pinonaldehyde (from $\alpha$-pinene), limonaldehyde (from limonene) and $\alpha$-terpinonaldehyde (from $\alpha$-terpinene) have different retention times and product ion mass spectra, allowing them to be differentiated. For each single precursor, there are often over a hundred isolated species and a structural analysis of the SOA components is very time consuming. Rather than attempt a structural characterisation of each compound, instead, an SOA library has been constructed (ACES library), containing the basic mass spectrum of each isolated SOA component.

A series of scripts were designed for use with the Bruker Compass Automation Engine Software. The first script plots extracted ion chromatograms for a user defined range of $\mathrm{m} / \mathrm{z}$ values, then carries out peak finding and integration. The peaks are labelled with their retention time and the associated product ion mass spectrum of the peak $\left(\mathrm{MS}^{2}\right)$. The second script exports each peak into the ACES library, labelled by its retention time and precursor. For example, pinonic acid is found in the library under the label " 26.5 apinene". Using this 
Table 1. Experimental details of chamber experiments used to build the mass spectral library.

\begin{tabular}{|c|c|c|c|c|c|c|c|c|c|}
\hline Exp Date & Exp \# & SOA Precursor & $\begin{array}{l}{[\mathrm{VOC}]_{0}^{1}} \\
\text { (ppbv) }\end{array}$ & $\begin{array}{l}{\left[\mathrm{NO}_{\mathrm{X}}\right]_{0}} \\
(\mathrm{ppbv})\end{array}$ & $\begin{array}{l}\mathrm{RH}^{2}( \pm \mathrm{sd}) \\
(\%)\end{array}$ & $\begin{array}{l}\operatorname{Temp}^{2}( \pm \mathrm{sd}) \\
\left({ }^{\circ} \mathrm{C}\right)\end{array}$ & $\begin{array}{l}\text { Duration } \\
\text { (h) }\end{array}$ & $\begin{array}{l}\text { Peak mass } \\
\text { concentration } \\
\left(\mu \mathrm{g} \mathrm{m}^{-3}\right)\end{array}$ & $\begin{array}{l}\text { Peak number } \\
\text { concentration } \\
\left(\mathrm{cm}^{-3}\right)\end{array}$ \\
\hline 12.03.2008 & 1 & $\beta$-caryophyllene & 50 & 34 & $53.9 \pm 0.6$ & $25.3 \pm 0.2$ & 04:04 & $>21.6$ & $2.63 \times 10^{4}$ \\
\hline 13.03 .2008 & 2 & $\beta$-caryophyllene & 250 & 117 & $49.4 \pm 0.6$ & $24.9 \pm 0.3$ & 04:03 & $>130.3$ & $3.39 \times 10^{4}$ \\
\hline 19.03 .2008 & 3 & Limonene & 50 & $\sim 40$ & $51.2 \pm 0.2$ & $25.0 \pm 0.1$ & $06: 00$ & $>33.4$ & $1.45 \times 10^{4}$ \\
\hline 28.03 .2008 & 4 & Limonene & 250 & 124 & $53.7 \pm 0.3$ & $25.1 \pm 0.1$ & 04:02 & $>140.1$ & $3.45 \times 10^{4}$ \\
\hline 08.04 .2008 & 5 & Limonene & 250 & 136 & $53.5 \pm 0.3$ & $25.3 \pm 0.1$ & 02:02 & $>128.2$ & $3.65 \times 10^{4}$ \\
\hline 10.04 .2008 & 6 & $\beta$-caryophyllene & 250 & 130 & $49.2 \pm 0.2$ & $24.7 \pm 0.1$ & 02:00 & $>125.3$ & $2.97 \times 10^{4}$ \\
\hline 16.04 .2008 & 7 & $\beta$-caryophyllene & 250 & 128 & $44.4 \pm 0.7$ & $26.1 \pm 0.3$ & $06: 02$ & 220.0 & $3.56 \times 10^{4}$ \\
\hline 17.04.2008 & 8 & Limonene & 250 & 142 & $49.1 \pm 0.8$ & $26.3 \pm 0.3$ & 06:02 & 382.4 & $3.26 \times 10^{4}$ \\
\hline 22.04 .2008 & 9 & Limonene & 50 & 54 & $54.3 \pm 0.2$ & $25.2 \pm 0.1$ & 02:00 & 52.2 & $1.51 \times 10^{4}$ \\
\hline 23.04 .2008 & 10 & $\beta$-caryophyllene & 50 & 31 & $53.4 \pm 0.7$ & $25.4 \pm 0.3$ & 02:00 & 50.1 & $2.94 \times 10^{4}$ \\
\hline 24.04 .2008 & 11 & $\beta$-caryophyllene & 50 & 28 & $47.9 \pm 0.9$ & $25.4 \pm 0.4$ & $05: 58$ & 65.6 & $2.48 \times 10^{4}$ \\
\hline 28.04 .2008 & 12 & Limonene & 50 & 32 & $53.6 \pm 0.6$ & $25.3 \pm 0.2$ & 04:01 & 31.1 & $1.67 \times 10^{4}$ \\
\hline 16.06 .2008 & 13 & Myrcene & 50 & 31 & $53.6 \pm 2.4$ & $25.8 \pm 1.1$ & 06:03 & 18.5 & $5.47 \times 10^{4}$ \\
\hline 17.06 .2008 & 14 & Myrcene & 250 & 137 & $51.3 \pm 2.7$ & $26.0 \pm 1.3$ & 06:00 & 134.8 & $1.62 \times 10^{5}$ \\
\hline 20.06 .2008 & 15 & Linalool & 50 & 29 & $48.0 \pm 0.4$ & $25.4 \pm 0.2$ & 06:06 & 7.4 & $6.54 \times 10^{4}$ \\
\hline 23.06 .2008 & 16 & Linalool & 250 & 122 & $52.7 \pm 1.6$ & $24.6 \pm 0.7$ & 06:03 & 53.2 & $1.8 \times 10^{5}$ \\
\hline 07.07 .2008 & 17 & Isoprene $^{5}$ & 300 & 36 & $68.5 \pm 1.3$ & $26.9 \pm 0.3$ & 04:00 & $15.6^{6}$ & $2.38 \times 10^{46}$ \\
\hline 10.07 .2008 & 18 & Limonene $^{7}$ & 50 & 75 & $71.9 \pm 1.0$ & $25.6 \pm 0.3$ & $07: 30$ & $44.8^{8}$ & $4.44 \times 10^{48}$ \\
\hline 11.07.2008 & 19 & $\alpha$-Pinene & 50 & 34 & $71.4 \pm 1.5$ & $25.6 \pm 0.5$ & 06:00 & 11.9 & $3.92 \times 10^{4}$ \\
\hline 25.04 .2008 & 20 & Background & Nil & 82.7 & $52.2 \pm 0.7$ & $25.5 \pm 0.3$ & 06:00 & 0.3 & $1.04 \times 10^{3}$ \\
\hline
\end{tabular}

1 Nominal concentration values estimated based on the amount introduced into the chamber without accounting for losses.

2 Average value for the experiment duration.

${ }^{3}$ Measured by a differential mobility particle sizer (DMPS) and assuming a particle density value of $1.3 \mathrm{~g} \mathrm{~cm}^{-3}$.

${ }^{4}$ Measured by a water based condensation particle counter (wCPC 3785, TSI Inc., USA)

5 On ammonium sulfate seed particles.

${ }^{6}$ Peak values for the seed particles, not for isoprene SOA.

7 On $\beta$-caryophyllene SOA seed particles.

${ }^{8}$ Peak values for the total seed and SOA particles.

system, all peaks are inserted into the library, rather than just the structurally identified species. The library also includes peaks from control samples, including water, methanol and blank filters extracted in the same way as the samples, to allow any background contaminants to be removed. Finally, a third script compares the field samples to the library and identifies any matches based on a series of user defined conditions.

The field samples were compared to the chamber samples using the library and the retention time and $\mathrm{MS}^{2}$ of each identified species was also manually compared to the chamber samples to ensure the library was functioning properly. Peaks also found in the blank samples have been ignored. Additional SOA tracer species, such as organosulfates, identified in previous literature as constituents of OA in forest locations, but not found in our chamber SOA, have also been investigated by manually studying the LC-MS ${ }^{2}$ data using extracted ion chromatograms. In total, eighteen SOA tracer compounds were found in the Borneo rainforest OA extract. A list of the molecular weight, retention time $\left(t_{\mathrm{R}}\right), \mathrm{MS}^{2}$ product ions observed and the suggested hydrocarbon precursor of the BSOA tracer compounds are shown in Table 2. The similarity of each BSOA tracer mass spectrum to the corresponding library spectrum are given in Table 1 as the Fit and Reverse Fit (Rfit) parameters out of 1000 (where 1000 is a perfect match both in terms of $\mathrm{m} / \mathrm{z}$ present and their intensi- ties, further details in SI Appendix). The majority of identified species have Fit and RFit values greater than 900 indicating the BSOA tracer has a very good fit to the library spectrum and visa versa. Retention time matching was also applied, with a maximum deviation of $1 \mathrm{~min}$ allowed, although the compounds identified here have a maximum deviation of only $0.2 \mathrm{~min}$ from the associated chamber peak.

In order to structurally identify the common oxygenated tracer compounds, commercially available standards and literature product ion mass spectra were used where available. In addition, some compounds were tentatively identified based on their $\mathrm{MS}^{2}$ product ions. Single ion chromatograms for the BSOA tracer ions found in the Borneo OA sample are shown in the Supplement Fig. 1. The Borneo OA chromatograms are complex, indicating that there may be additional BSOA tracers from other monoterpenes and sesquiterepenes that have not been identified. The product ion mass spectra for all eighteen compounds are given in the Supplement Figs. S2-18. Where compounds have been identified based on $\mathrm{MS}^{2}$ patterns, the high resolution FTICRMS data was used to determine if a matching component of the correct molecular formula was present. Molecular formulae matching all of the identified BSOA tracers were found with calculated mass accuracies below $0.7 \mathrm{ppm}$, well within acceptable errors, and are given in Table 2 along with the measured $m / z$ and error (ppm). 
Table 2. BSOA tracer compounds identified using LC-MS ${ }^{2}$ in ambient aerosol collected at Danum Valley, Borneo in order of retention on the LC column. Accurate masses were obtained using syringe pump infusion ESI-FTICRMS in negative ionisation mode. Numbers in bold are the base peak in the $\mathrm{MS}^{2}$ mass spectra.

\begin{tabular}{|c|c|c|c|c|c|c|c|c|c|c|}
\hline MW & {$[\mathrm{M}-\mathrm{H}]^{-}$} & $t_{\mathrm{R}}(\mathrm{mins})$ & Fragment ions & $\begin{array}{l}\text { Suggested } \\
\text { precursor }\end{array}$ & $\begin{array}{l}\text { Library fit } \\
\text { (out of } \\
1000 \text { ) }\end{array}$ & $\begin{array}{l}\text { Reverse } \\
\text { library fit } \\
\text { (out of } \\
1000 \text { ) }\end{array}$ & $\begin{array}{l}\text { Proposed } \\
\text { identity }\end{array}$ & $\begin{array}{l}\text { Matching peaks } \\
\text { in FTICR-MS }\end{array}$ & $\begin{array}{l}\text { Measured } \\
\mathrm{m} / \mathrm{z}\end{array}$ & $\begin{array}{l}\text { error } \\
(\mathrm{ppm})\end{array}$ \\
\hline 216 & 215 & 2.9 & 97 & isoprene & a & a & $\begin{array}{l}\text { 2-methyl tetrol } \\
\text { OS }\end{array}$ & $\mathrm{C}_{5} \mathrm{H}_{11} \mathrm{O}_{7} \mathrm{~S}$ & 215.02311 & -0.07 \\
\hline 334 & 333 & 3.6 & $315,197,97$ & isoprene & $\mathrm{a}$ & $\mathrm{a}$ & $\begin{array}{l}\mathrm{C}_{5} \text {-epoxydiol } \\
\text { dimer OS }\end{array}$ & none & & \\
\hline 188 & 187 & 4.2 & $171, \mathbf{1 1 5}$ & limonene & 1000 & 1000 & n.i. & & & \\
\hline 204 & 203 & 4.7 & $185, \mathbf{1 4 1}, 111$ & limonene & 901 & 953 & n.i. & & & \\
\hline 170 & 169 & 5.1 & 151 & $\alpha$-terpinene & $\mathrm{b}$ & $\mathrm{b}$ & $\begin{array}{l}\alpha \text {-terpinalic } \\
\text { acid }\end{array}$ & $\mathrm{C}_{9} \mathrm{H}_{13} \mathrm{O}_{3}$ & 169.08703 & -0.05 \\
\hline 188 & 187 & 8 & $169, \mathbf{1 4 3}, 125,111$ & limonene & 962 & 994 & n.i. & & & \\
\hline 188 & 187 & 9.5 & $169, \mathbf{1 2 5}$ & $\alpha$-pinene & 1000 & 997 & n.i. & & & \\
\hline 188 & 187 & 10.8 & $169,143,125,115$ & limonene & 866 & 614 & $\begin{array}{l}\text { ketolimonic } \\
\text { acid }\end{array}$ & $\mathrm{C}_{8} \mathrm{H}_{11} \mathrm{O}_{5}$ & 187.06117 & 0.14 \\
\hline 158 & 157 & 12 & 113 & $\alpha$-pinene & 1000 & 1000 & terebic acid & $\mathrm{C}_{7} \mathrm{H}_{9} \mathrm{O}_{4}$ & 157.05136 & 0.2 \\
\hline 172 & 171 & 14.1 & 153,127 & $\alpha$-pinene & 997 & 1000 & terpenylic acid & $\mathrm{C}_{8} \mathrm{H}_{11} \mathrm{O}_{4}$ & 171.0671 & 0.3 \\
\hline 204 & 203 & 15.8 & 185 & $\alpha$-pinene & 994 & 994 & MBTCA & $\mathrm{C}_{8} \mathrm{H}_{11} \mathrm{O}_{6}$ & 203.05609 & 0.09 \\
\hline 186 & 185 & 15.8 & $141,97,71$ & $\alpha$-pinene & 888 & 922 & $\begin{array}{l}\text { fragment of } \\
\text { MBTCA }\end{array}$ & & & \\
\hline 216 & 215 & 16.1 & 197, 171, 153, & $\begin{array}{l}\beta \text { - } \\
\text { caryophyllene }\end{array}$ & 603 & 841 & n.i. & & & \\
\hline 216 & 215 & 22.8 & 197,153 & $\alpha$-pinene & 912 & 983 & n.i. & $\mathrm{C}_{10} \mathrm{H}_{15} \mathrm{O}_{5}$ & 215.09251 & -0.07 \\
\hline 172 & 171 & 26.4 & 127 & limonene & 1000 & 991 & $\begin{array}{l}\text { ketolimonalic } \\
\text { acid }\end{array}$ & $\mathrm{C}_{8} \mathrm{H}_{11} \mathrm{O}_{4}$ & 171.06628 & 0.3 \\
\hline 184 & 183 & 26.5 & 139 & $\alpha$-pinene & $\mathrm{b}$ & $\mathrm{b}$ & cis-pinonic acid & $\mathrm{C}_{10} \mathrm{H}_{15} \mathrm{O}_{3}$ & 183.10263 & 0.18 \\
\hline 254 & 253 & 35.4 & $235,211,191$ & $\begin{array}{l}\beta- \\
\text { caryophyllene }\end{array}$ & 993 & 975 & $\begin{array}{l}\text { b- } \\
\text { nocaryophyllonic } \\
\text { acid }\end{array}$ & $\mathrm{C}_{14} \mathrm{H}_{21} \mathrm{O}_{4}$ & 253.1447 & -0.68 \\
\hline 254 & 253 & 44.4 & 209, 191 & Sesquiterpene & 953 & 993 & rt mismatch & & & \\
\hline
\end{tabular}

\subsection{Isoprene SOA}

The first isoprene SOA tracer compound in the Danum samples with $\mathrm{MW}=216 \mathrm{Da}$ and $t_{\mathrm{R}}=2.9 \mathrm{~min}$ has been identified as 2-methyl tetrol organosulfate based on the reference product ion spectrum in (Gomez-Gonzalez et al., 2008), showing a major fragment ion at $\mathrm{m} / \mathrm{z} 97\left(\mathrm{HSO}_{4}^{-}\right)$. A matching molecular formula $\left([\mathrm{M}-\mathrm{H}]^{-}=\mathrm{C}_{5} \mathrm{H}_{11} \mathrm{O}_{7} \mathrm{~S}\right)$ was seen in the FTICRMS analysis, with an error of $-0.07 \mathrm{ppm}$. A compound with $\mathrm{MW}=334 \mathrm{Da}$ and at $t_{\mathrm{R}}=3.6 \mathrm{~min}$, showed fragment ions of $315,215,197$ and $97 \mathrm{Da}$ and is identified as a C5-epoxydiol dimer organosulfate based on comparison to a reference spectrum in Fig. 31b in Surratt et al. (2008) and updated in Surratt et al. (2010). No matching formula was found in the FTICRMS data.

\section{$3.2 \alpha$-pinene SOA}

A total of $6 \alpha$-pinene SOA tracer compounds were found in the ambient samples. One compound had a MW 158 and $t_{\mathrm{R}}=12.0 \mathrm{~min}$. This has been assigned as terebic acid using the reference product ion spectrum in Yasmeen et al. (2011). This is also an oxidation product of $\Delta 3$-carene. The chamber mass spectrum of this peak shows the expected non- covalently bonded dimer formation at $\mathrm{m} / \mathrm{z} 337$. This was not seen in the ambient mass spectrum, which may be a consequence of lower concentrations or an ion suppression effect. A compound with MW 172 and $t_{\mathrm{R}}=14.1 \mathrm{~min}$ was identified as terpenylic acid using the reference product ion spectrum in Yasmeen et al. (2010) although no $\mathrm{MS}^{3}$ has been carried out for confirmation. The compound with MW 184 and $t_{\mathrm{R}}=26.5 \mathrm{~min}$ was identified as cis-pinonic acid using a commercially available standard. The retention time matched but no $\mathrm{MS}^{2}$ data was available from the rainforest OA sample for confirmation due to very low ion intensity and overlapping signals. The compound with MW 188 and a $t_{\mathrm{R}}=9.5 \mathrm{~min}$ was seen in both the $\alpha$-pinene SOA and the ambient samples. It has not been possible to identify this compound. The product ion mass spectrum is very similar to an unidentified compound found by Yasmeen et al. (2011) in K-puszta aerosol (Fig. A4b in Yasmeen et al., 2011). The compound with MW 204 and $t_{\mathrm{R}}=15.7$ min was identified as 3-methyl1,2,3-butanetricarboxylic acid (MBTCA) using the reference product ion spectrum in Yasmeen et al., (Yasmeen et al., 2011) with the $\mathrm{MS}^{3}$ product ion mas spectrum of $\mathrm{m} / z 185$ being a very close match in terms of fragments and intensities. The unidentified $\alpha$-pinene tracer with MW 216 and 
$t_{\mathrm{R}}=22.8 \mathrm{~min}$ may correspond to a compound identified with the FTICRMS with the molecular formula $\mathrm{C}_{10} \mathrm{H}_{16} \mathrm{O}_{5}$. An identical, highly oxidised molecular formula, was seen by (Warscheid and Hoffmann, 2002) from SOA generated by $\alpha$-pinene ozonolysis, although the fragmentation patterns are not consistent.

\subsection{Limonene SOA}

Five limonene SOA tracer compounds were found in the rainforest samples, where both the retention time and library spectrum show good matches. The compound with MW 172 and $t_{\mathrm{R}}=26.4 \mathrm{~min}$ has a good library fit (Fit 1000, Rfit 991) with a chamber limonene SOA compound. This compound is tentatively identified as ketolimonalic acid due to the loss of $44 \mathrm{Da}\left(\mathrm{CO}_{2}\right)$ indicating a carboxylic acid. Three compounds were identified with a MW 188. The first of these at a $t_{\mathrm{R}}=4.2 \mathrm{~min}$ shows losses of $16 \mathrm{Da}$ and $72 \mathrm{Da}$ and remains unidentified at present. The second peak at $t_{\mathrm{R}}=8 \mathrm{~min}$ has losses of $18 \mathrm{Da}\left(\mathrm{H}_{2} \mathrm{O}\right), 44 \mathrm{Da}\left(\mathrm{CO}_{2}\right), 62 \mathrm{Da}\left(\mathrm{H}_{2} \mathrm{O}+\mathrm{CO}_{2}\right)$ and $76 \mathrm{Da}$ and is also unidentified. The product ion mass spectrum is very similar to an unidentified compound found by Yasmeen et al. (2011, Fig. A4a) in K-puszta aerosol. The third compound with $t_{\mathrm{R}}=10.8 \mathrm{~min}$ has losses of $18 \mathrm{Da}$ $\left(\mathrm{H}_{2} \mathrm{O}\right), 44 \mathrm{Da}\left(\mathrm{CO}_{2}\right), 62 \mathrm{Da}\left(\mathrm{H}_{2} \mathrm{O}+\mathrm{CO}_{2}\right)$ and $72 \mathrm{Da}$. We have assigned this peak as ketolimonic acid as the fragmentation pattern is very similar to limonic acid (Yasmeen et al., 2011) but with product ions $2 \mathrm{Da}$ higher reflecting the change of the alkene to a carbonyl functionality. A compound with $\mathrm{MW}$ $204, t_{\mathrm{R}}=4.7 \mathrm{~min}$ and losses of $18 \mathrm{Da}\left(\mathrm{H}_{2} \mathrm{O}\right), 44 \mathrm{Da}\left(\mathrm{CO}_{2}\right)$, $62 \mathrm{Da}\left(\mathrm{H}_{2} \mathrm{O}+\mathrm{CO}_{2}\right)$ and $92 \mathrm{Da}$ is not identified at present.

\section{$3.4 \alpha$-terpinene SOA}

One compound was identified as a $\alpha$-terpinene SOA tracer, with a MW 170 and $t_{\mathrm{R}}=5.1 \mathrm{~min}$. This has been tentatively identified as $\alpha$-terpinalic acid. However, the product ion mass spectrum shows only a loss of $18 \mathrm{Da}\left(\mathrm{H}_{2} \mathrm{O}\right)$ and without a standard it is not possible to confirm this assignment at present. There is a matching molecular formula $\left(\mathrm{C}_{9} \mathrm{H}_{14} \mathrm{O}_{3}\right)$ in the FTICRMS data, with a mass accuracy of $-0.05 \mathrm{ppm}$.

\section{$3.5 \quad \beta$-caryophyllene SOA}

Two $\beta$-caryophyllene SOA tracers were identified in the rainforest OA extract. The first of these has a MW 216 and $t_{\mathrm{R}}=16.1 \mathrm{~min}$ and shows losses of $18 \mathrm{Da}\left(\mathrm{H}_{2} \mathrm{O}\right), 44 \mathrm{Da}\left(\mathrm{CO}_{2}\right)$, $62 \mathrm{Da}\left(\mathrm{H}_{2} \mathrm{O}+\mathrm{CO}_{2}\right) 88 \mathrm{Da}$ and $102 \mathrm{Da}$. The loss of $88 \mathrm{Da}$ may represent two losses of $\mathrm{CO}_{2}$, indicating a diacid structure. The compound with MW 254 and $t_{\mathrm{R}}=35.4 \mathrm{~min}$ is identified as $\beta$-nocaryophyllonic acid (Jaoui et al., 2007) based on previously published work, although there is a difference in retention time as a result of using a different method (Alfarra et al., 2012). An additional tracer compound was also identified with a MW 254 and $t_{\mathrm{R}}=44.4 \mathrm{~min}$. This showed a very similar product ion mass spectrum to a $\beta$-caryophyllene SOA component in the library (Fit 953, RFit 993) but the retention time did not match. It is hypothesized that this represents SOA from a different sesquiterpene and is not identified at present.

\subsection{Molecular composition}

The rainforest OA extract was also analysed using FTICRMS to obtain information on the elemental composition. Just under 1000 monoisotopic compounds were found in the filter extracts. Compounds were screened to remove unlikely molecular formulae. Compounds were removed from the list if they contained any of the following; $\mathrm{H}: \mathrm{C}<0.5, \mathrm{O}: \mathrm{C}>3$ and a double bond equivalent $(\mathrm{DBE})>20$. Around 200 peaks were removed using this screening process. The list still includes a number of formulae that are difficult to explain, such as $\mathrm{C}_{10} \mathrm{H}_{5} \mathrm{OS}$, but these have been kept in the analysis. Molecular formulae showed the presence of compounds containing $\mathrm{C}, \mathrm{H}$ and $\mathrm{O}(\mathrm{CHO})$, containing $\mathrm{C}, \mathrm{H}, \mathrm{O}, \mathrm{N}(\mathrm{CHON})$, containing $\mathrm{C}, \mathrm{H}, \mathrm{O}$ and $\mathrm{S}(\mathrm{CHOS})$, containing $\mathrm{C}, \mathrm{H}, \mathrm{O}, \mathrm{N}$ and $\mathrm{S}$ (CHONS) and non-oxygen containing (CHN, CHS and CHNS) (LeClair et al., 2012). In total, 554 CHO, 203 CHON, 109 CHOS, 104 CHONS, and 23 CHN/CHS/CHNS formulae were identified and a full list is given in the Supplement Tables S1-S5. The CHO compounds are by far the most abundant group, representing $71 \%$ of the total ion count of all identified species as shown in the Supplement Table S6.

In addition to the BSOA tracers identified in the LC-MS analysis, a number of other molecular formulae were obtained that may correspond to BSOA tracers and these are given in Table 3. These formulae correspond to organosulfates from isoprene and monoterpenes, which have been previously detected in chamber and in ambient aerosol. Five formulae match isoprene OS including the MW 216 identified previously (Surratt et al., 2008). In addition there is $\mathrm{C}_{5} \mathrm{H}_{10} \mathrm{NO}_{9} \mathrm{~S}$, that matches an isoprene nitroxy organosulfate identified in isoprene SOA (Surratt et al., 2008) and ambient aerosol at K-puszta in Hungary, a mixed deciduous/coniferous forested site (Gomez-Gonzalez et al., 2008). Six formulae were found that match monoterpenoid OS compounds, seen in chamber generated limonene or $\alpha$-pinene SOA (Surratt et al., 2008). However, these compounds were either below the threshold for $\mathrm{MS}^{2}$ analysis or were below the limit of detection of the LC-MS analysis and without standards or product ion mass spectra it is impossible to confirm the identity of these species. There are other sources that may contribute to these OS species (Shalamzari et al., 2013; Surratt et al., 2008), for example the MW 214 species may be related to 2- or 4-pentenal SOA (Gomez-Gonzalez et al., 2008). The formation pathways of organosulfates remains unclear with epoxides from isoprene and methacrylic acid oxidation (Lin et al., 2013) and sulfate radical chemistry (Nozière et al., 2010; Schindelka et al., 2013) both potential routes. 
Table 3. Isoprene and monoterpene organosulfates identified using FTICRMS in ambient aerosol collected at Danum Valley, Borneo.

\begin{tabular}{lrcccc}
\hline Observed $m / z$ & Error $(\mathrm{ppm})$ & Proposed Formula $[\mathrm{M}-\mathrm{H}]^{-}$ & $\mathrm{O}: \mathrm{C}$ & $\mathrm{H}: \mathrm{C}$ & Isoprene or Monoterpene \\
\hline 152.986326 & -0.05 & $\mathrm{C}_{3} \mathrm{H}_{5} \mathrm{O}_{5} \mathrm{~S}$ & 1.67 & 1.67 & isoprene \\
198.992003 & -1.03 & $\mathrm{C}_{4} \mathrm{H}_{7} \mathrm{O}_{7} \mathrm{~S}$ & 1.75 & 1.75 & isoprene \\
210.991775 & 0.10 & $\mathrm{C}_{5} \mathrm{H}_{7} \mathrm{O}_{7} \mathrm{~S}$ & 1.40 & 1.40 & isoprene \\
213.007602 & -0.73 & $\mathrm{C}_{5} \mathrm{H}_{9} \mathrm{O}_{7} \mathrm{~S}$ & 1.40 & 1.80 & isoprene \\
215.023112 & -0.07 & $\mathrm{C}_{5} \mathrm{H}_{11} \mathrm{O}_{7} \mathrm{~S}$ & 1.40 & 2.20 & isoprene \\
223.028166 & 0.07 & $\mathrm{C}_{7} \mathrm{H}_{11} \mathrm{O}_{6} \mathrm{~S}$ & 0.86 & 1.57 & monoterpene \\
226.986808 & -0.42 & $\mathrm{C}_{5} \mathrm{H}_{7} \mathrm{O}_{8} \mathrm{~S}$ & 1.60 & 1.40 & monoterpene \\
251.059918 & -1.74 & $\mathrm{C}_{9} \mathrm{H}_{15} \mathrm{O}_{6} \mathrm{~S}$ & 0.67 & 1.67 & monoterpene \\
260.008391 & -0.83 & $\mathrm{C}_{5} \mathrm{H}_{10} \mathrm{NO}_{9} \mathrm{~S}$ & 1.80 & 2.00 & isoprene \\
265.07574 & -2.29 & $\mathrm{C}_{10} \mathrm{H}_{17} \mathrm{O}_{6} \mathrm{~S}$ & 0.60 & 1.70 & monoterpene \\
279.055453 & -3.79 & $\mathrm{C}_{10} \mathrm{H}_{15} \mathrm{O}_{7} \mathrm{~S}$ & 0.70 & 1.50 & monoterpene \\
297.066003 & -3.50 & $\mathrm{C}_{10} \mathrm{H}_{17} \mathrm{O}_{8} \mathrm{~S}$ & 0.80 & 1.70 & monoterpene \\
\hline
\end{tabular}

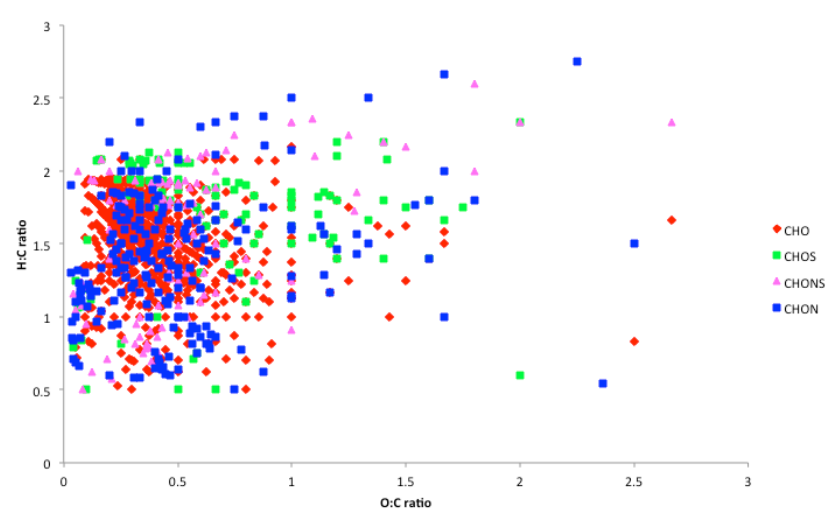

Fig. 2. Van Krevelen plot of calculated $\mathrm{O}: \mathrm{C}$ and $\mathrm{H}: \mathrm{C}$ ratios from the Borneo rainforest OA sample extract determined using FTICR. Red $=$ CHO compounds. Blue $=\mathrm{CHON}$ compounds. Green $=\mathrm{CHOS}$ compounds. Pink $=$ CHONS compounds.

Van Krevelen plots, where the $\mathrm{H}: \mathrm{C}$ ratio is plotted against the $\mathrm{O}: \mathrm{C}$ ratio, are useful tools for investigating complex data sets such as organic aerosol and have been used in a number of studies (Bateman et al., 2010; Nizkorodov et al., 2011; Reinhardt et al., 2007; Saranjampour et al., 2011). The elemental ratios calculated for the rainforest OA extract were used to produce a Van Krevelen plot, shown in Fig. 2, with different coloured labels used for the different group classifications. The intensity weighted mean atomic ratios were calculated according to (Bateman et al., 2010) and gives values of $\mathrm{O}: \mathrm{C}=0.37, \mathrm{H}: \mathrm{C}=1.56, \mathrm{~N}: \mathrm{C}=0.026, \mathrm{~S}: \mathrm{C}=0.013$ and $\mathrm{OM}: \mathrm{OC}=1.63$. The majority of the $\mathrm{CHO}$ compounds (red diamonds in Fig. 2) have $\mathrm{O}: \mathrm{C}$ ratios less than 1 and calculating an intensity weighted mean gives a value of 0.37 . The majority of the species with $\mathrm{O}: \mathrm{C}$ ratio greater than 1 , fall into the three other oxidised groups and calculating intensity weighted mean $\mathrm{O}: \mathrm{C}$ ratios gave values of 0.62 (CHOS), $0.58(\mathrm{CHON})$ and 0.53 (CHONS) suggesting the occurrence of organosulfates and organonitrates.
The average $\mathrm{O}: \mathrm{C}$ and $\mathrm{H}: \mathrm{C}$ ratios fit with the emerging pattern of bulk OA composition and would sit very close to the line of -1 slope on a Van Krevelen plot as seen for ambient data from other locations (Heald et al., 2010). The elemental ratios of the sub micron organic aerosol were determined using a HR-AMS and the $10 \mathrm{~min}$ averaged data for the OP3 measurement campaign are shown in Fig. 3. The majority of the points have $\mathrm{O}: \mathrm{C}$ ratios within the range 0.25 to 0.75 , with an average value of 0.49 . There is a good correlation present with $R^{2}=0.80$, and a line of best fit through all the points has a gradient of -0.8 and an intercept of 1.75 . During a period of biomass burning influence at the start of the campaign (blue stars), the $\mathrm{O}: \mathrm{C}$ ratio is higher with an mean value and standard deviation of $0.56 \pm 0.06$, compared to the remainder of the campaign (red crosses) which had a mean value of $0.47 \pm 0.07$, although care should be taken in this interpretation due to the overlap of uncertainties. During AMAZE-08, Chen et al. (2009) observed a O : C ratio of 0.42 from organic aerosol during periods of in-basin sources in Amazonia compared to 0.49 for periods of out of basin influence. Trajectory analysis indicates that the Borneo site is strongly influenced by aged regional background from off island sources and that although the rainforest and adjacent oil palm plantations are sources of BSOA, there are no periods where BSOA dominates as in the case of the AMAZE-08 project (Robinson et al., 2011b). Thus the averaged $\mathrm{O}: \mathrm{C}$ ratio for OP3 is consistent with the out of basin values obtained from the Amazon.

\subsection{Comparison of $\mathrm{O}: \mathrm{C}$ ratios}

The $\mathrm{O}: \mathrm{C}$ value obtained by FTICRMS (0.37) is lower than the average AMS value but they are remarkably close considering the different instrumentation and size fractions collected. The AMS analyses the sub micron non-refractory composition, whereas the FTICR-MS analyses the watersoluble extract of $\mathrm{PM}_{2.5}$. There are significant amounts of primary biological aerosol particles (PBAP) between 1 and 


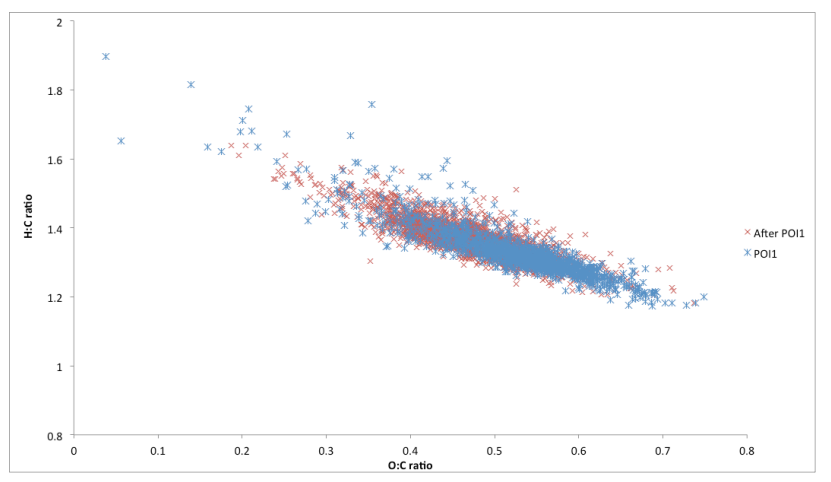

Fig. 3. Van Krevelen plot of 10 minute average $\mathrm{O}: \mathrm{C}$ and $\mathrm{H}: \mathrm{C}$ ratios determined using HR-AMS. Blue crosses indicate ratios measured during a period of increased biomass burning influence (POI1). Red crosses indicate the measurements taken after PO1 when lower pollution levels were seen.

$2.5 \mu \mathrm{m}$ and these may act as a source of less oxidised material, such as fatty acids and biological molecules, if the cells lyse during the extraction procedure (Gabey et al., 2010). The HR-AMS may also be able to measure highly oxidised species that are not amenable to the FTICR-MS analysis. It should also be noted that the HR-AMS value represents a campaign average of many AMS spectra, whereas the FTICRMS value represent a single analysis of a months worth of collected aerosol.

\section{Discussion}

BVOCs are predicted to make a significant contribution to SOA formation in tropical regions, but it is difficult to really understand their role without the identification of compound specific SOA tracers. In this study, chamber simulations of important BVOCs given off from tree species in a tropical rainforest in Borneo were used to identify BSOA tracers of a range of biogenic precursors. In total 18 precursor specific BSOA tracer compounds were identified using LC-MS. It is clear that the OA at Danum Valley in Borneo contains products from the oxidation of isoprene, monoterpenes and sesquiterpenes in the ambient SOA. Isoprene oxidation products have previously been seen in a range of forest ecosystems; 2-methyl tetrols were identified as isoprene SOA tracers by Claeys et al. (2004) in Amazonia and have subsequently been identified in many locations. As mentioned previously Robinson et al. (2011a) identified a AMS factor that was linked to isoprene SOA at this location which has subsequently been seen in other high isoprene areas. This factor has recently been linked to the acid catalysed reactions of isoprene epoxides (IEPOX) to 3-methyltetrahydrofuran-3,4diols (Lin et al., 2012). The 2-methyl tetrol organosulfates have been identified in the Southeastern USA and Europe. They have also been identified above a tropical forest, where pollution levels are generally much lower, using a single particle mass spectrometer (PALMS) on an aircraft platform (Froyd). The current study confirms the presence of IEPOX organosulfates and indicates that they can also be present close to the top of the canopy in a tropical forest. AMS measurements carried out during OP3 indicated that the sub micron aerosol over Borneo had a much higher sulfate : organic ratio than that seen in Amazonia, which has been attributed to marine sulfate sources, and that Borneo is often influenced by significant off island sources such as biomass burning. Oxidation of dimethylsulfide emitted from the surrounding maritime source may provide an acidic aerosol surface, which may catalyse organosulfate formation from IEPOX. Other possible pathways are that the interaction of more polluted air from biomass burning with the pristine forest environment may enhance the formation of organosulfates over the forest or it may be that the organosulfates are transported onto the island through long-range transport. Further work is needed to understand the formation of these compounds in regions such as Borneo where tropical forests are subject to periods of anthropogenic pollution.

Isoprene was the most abundant VOC measured during OP3, with a mean daytime maximum mixing ratio of around $2 \mathrm{ppb}$. Other VOCs observed directly in Danum include a small range of monoterpenes, however this speciation is unlikely to represent all monoterpenes present. Sesquiterpenes were not observed in the gas phase but were believed to be present given leaf cuvette observations. A number of tracers, particularly those from $\alpha$-pinene have been identified in ambient aerosol in boreal and temperate forests, where monoterpene emissions often dominate over isoprene.. However, this study provides the first unambiguous identification of monoterpene and sesquiterpene SOA in a tropical rainforest.

\section{Supplementary material related to this article is available online at http://www.atmos-chem-phys.net/13/ 11295/2013/acp-13-11295-2013-supplement.pdf.}

Acknowledgements. This work was supported by the UK Natural Environment Research Council through the OP3 (grant NE/D002117/1) and ACES (grant NE/E011179/1) projects. We thank the Malaysian and Sabah Governments for their permission to conduct research in Malaysia; the Malaysian Meteorological Department for access to the measurement site; Yayasan Sabah and the Royal Society's Southeast Asian Rain Forest Research Programme for logistical support. This is paper number 529 of the Royal Society's Southeast Asian Rainforest Research Programme. JFH thanks B. Langford and G. Edwards for helping to move the sampler to canopy site. FTICR-MS facilities were made available by the University of York Centre of Excellence in Mass Spectrometry, which was created thanks to a major capital investment through Science City York, supported by Yorkshire Forward with funds from the Northern Way Initiative. 
Edited by: A. Kiendler-Scharr

\section{References}

Alfarra, M. R., Hamilton, J. F., Wyche, K. P., Good, N., Ward, M. W., Carr, T., Barley, M. H., Monks, P. S., Jenkin, M. E., Lewis, A. C., and McFiggans, G. B.: The effect of photochemical ageing and initial precursor concentration on the composition and hygroscopic properties of ?-caryophyllene secondary organic aerosol, Atmos. Chem. Phys., 12, 6417-6436, doi:10.5194/acp12-6417-2012, 2012.

Andreae, M. O., Artaxo, P., Brandao, C., Carswell, F. E., Ciccioli, P., da Costa, A. L., Culf, A. D., Esteves, J. L., Gash, J. H. C., Grace, J., Kabat, P., Lelieveld, J., Malhi, Y., Manzi, A. O., Meixner, F. X., Nobre, A. D., Nobre, C., Ruivo, M., Silva-Dias, M. A., Stefani, P., Valentini, R., von Jouanne, J., and Waterloo, M. J.: Biogeochemical cycling of carbon, water, energy, trace gases, and aerosols in Amazonia: The LBA-EUSTACH experiments, J. Geophys. Res.-Atmos., 107, 8066, doi:10.1029/2001JD000524, 2002.

Bateman, A. P., Nizkorodov, S. A., Laskin, J., and Laskin, A.: High-Resolution Electrospray Ionization Mass Spectrometry Analysis of Water-Soluble Organic Aerosols Collected with a Particle into Liquid Sampler, Anal. Chem., 82, 8010-8016, doi:10.1021/ac1014386, 2010.

Bonn, B. and Moortgat, G. K.: Sesquiterpene ozonolysis: Origin of atmospheric new particle formation from biogenic hydrocarbons, Geophys. Res. Lett., 30, 1585, doi:10.1029/2003GL017000, 2003.

Capes, G., Murphy, J. G., Reeves, C. E., McQuaid, J. B., Hamilton, J. F., Hopkins, J. R., Crosier, J., Williams, P. I., and Coe, H.: Secondary organic aerosol from biogenic VOCs over West Africa during AMMA, Atmos. Chem. Phys., 9, 3841-3850, doi:10.5194/acp-9-3841-2009, 2009.

Chen, Q., Farmer, D. K., Schneider, J., Zorn, S. R., Heald, C. L., Karl, T. G., Guenther, A., Allan, J. D., Robinson, N., Coe, H., Kimmel, J. R., Pauliquevis, T., Borrmann, S., Pöschl, U., Andreae, M. O., Artaxo, P., Jimenez, J. L., and Martin, S. T.: Mass spectral characterization of submicron biogenic organic particles in the Amazon Basin, Geophys. Res. Lett., 36, L20806, doi:10.1029/2009g1039880, 2009.

Claeys, M., Graham, B., Vas, G., Wang, W., Vermeylen, R., Pashynska, V., Cafmeyer, J., Guyon, P., Andreae, M. O., Artaxo, P., and Maenhaut, W.: Formation of secondary organic aerosols through photooxidation of isoprene, Science, 303, 1173-1176, doi:10.1126/science.1092805, 2004.

Gabey, A. M., Gallagher, M. W., Whitehead, J., Dorsey, J. R., Kaye, P. H., and Stanley, W. R.: Measurements and comparison of primary biological aerosol above and below a tropical forest canopy using a dual channel fluorescence spectrometer, Atmos. Chem. Phys., 10, 4453-4466, doi:10.5194/acp-10-4453-2010, 2010.

Gomez-Gonzalez, Y., Surratt, J. D., Cuyckens, F., Szmigielski, R., Vermeylen, R., Jaoui, M., Lewandowski, M., Offenberg, J. H., Kleindienst, T. E., Edney, E. O., Blockhuys, F., Van Alsenoy, C., Maenhaut, W., and Claeys, M.: Characterization of organosulfates from the photooxidation of isoprene and unsaturated fatty acids in ambient aerosol using liquid chromatography/(-) electrospray ionization mass spectrometry, Journal of Mass Spectrometry, 43, 371-382, doi:10.1002/jms.1329, 2008.
Guenther, A., Hewitt, C. N., Erickson, D., Fall, R., Geron, C., Graedel, T., Harley, P., Klinger, L., Lerdau, M., McKay, W. A., Pierce, T., Scholes, B., Steinbrecher, R., Tallamraju, R., Taylor, J., and Zimmerman, P.: A global-model of natural volatile organic-compound emissions, J. Geophys. Res.-Atmos., 100, 8873-8892, doi:10.1029/94JD02950, 1995.

Guenther, A., Karl, T., Harley, P., Wiedinmyer, C., Palmer, P. I., and Geron, C.: Estimates of global terrestrial isoprene emissions using MEGAN (Model of Emissions of Gases and Aerosols from Nature), Atmos. Chem. Phys., 6, 3181-3210, doi:10.5194/acp-63181-2006, 2006.

Hamilton, J. F., Alfarra, M. R., Wyche, K. P., Ward, M. W., Lewis, A. C., McFiggans, G. B., Good, N., Monks, P. S., Carr, T., White, I. R., and Purvis, R. M.: Investigating the use of secondary organic aerosol as seed particles in simulation chamber experiments, Atmos. Chem. Phys., 11, 5917-5929, doi:10.5194/acp11-5917-2011, 2011.

Heald, C. L., Kroll, J. H., Jimenez, J. L., Docherty, K. S., DeCarlo, P. F., Aiken, A. C., Chen, Q., Martin, S. T., Farmer, D. K., and Artaxo, P.: A simplified description of the evolution of organic aerosol composition in the atmosphere, Geophys. Res. Lett., 37, L08803, doi:10.1029/2010g1042737, 2010.

Hewitt, C. N., Lee, J. D., MacKenzie, A. R., Barkley, M. P., Carslaw, N., Carver, G. D., Chappell, N. A., Coe, H., Collier, C., Commane, R., Davies, F., Davison, B., Di Carlo, P., Di Marco, C. F., Dorsey, J. R., Edwards, P. M., Evans, M. J., Fowler, D., Furneaux, K. L., Gallagher, M., Guenther, A., Heard, D. E., Helfter, C., Hopkins, J., Ingham, T., Irwin, M., Jones, C., Karunaharan, A., Langford, B., Lewis, A. C., Lim, S. F., MacDonald, S. M., Mahajan, A. S., Malpass, S., McFiggans, G., Mills, G., Misztal, P., Moller, S., Monks, P. S., Nemitz, E., Nicolas-Perea, V., Oetjen, H., Oram, D. E., Palmer, P. I., Phillips, G. J., Pike, R., Plane, J. M. C., Pugh, T., Pyle, J. A., Reeves, C. E., Robinson, N. H., Stewart, D., Stone, D., Whalley, L. K., and Yin, X.: Overview: oxidant and particle photochemical processes above a south-east Asian tropical rainforest (the OP3 project): introduction, rationale, location characteristics and tools, Atmos. Chem. Phys., 10, 169-199, doi:10.5194/acp-10-169-2010, 2010.

Jaoui, M., Lewandowski, M., Kleindienst, T. E., Offenberg, J. H., and Edney, E. O.: $\beta$-caryophyllinic acid: An atmospheric tracer for $\beta$-caryophyllene secondary organic aerosol, Geophys. Res. Lett., 34, L05816, doi:10.1029/2006g1028827, 2007.

Jones, C. E., Hopkins, J. R., and Lewis, A. C.: In situ measurements of isoprene and monoterpenes within a south-east Asian tropical rainforest, Atmos. Chem. Phys., 11, 6971-6984, doi:10.5194/acp-11-6971-2011, 2011.

Kallio, M., Jussila, M., Rissanen, T., Anttila, P., Hartonen, K., Reissell, A., Vreuls, R., Adahchour, M., and Hyotylainen, T.: Comprehensive two-dimensional gas chromatography coupled to time-of-flight mass spectrometry in the identification of organic compounds in atmospheric aerosols from coniferous forest, J. Chromatogr. A, 1125, 234-243, doi:10.1016/j.chroma.2006.05.050, 2006.

Kristensen, K., and Glasius, M.: Organosulfates and oxidation products from biogenic hydrocarbons in fine aerosols from a forest in North West Europe during spring, Atmos. Environ., 45, 45464556, doi:10.1016/j.atmosenv.2011.05.063, 2011.

LeClair, J. P., Collett, J. L., and Mazzoleni, L. R.: Fragmentation Analysis of Water-Soluble Atmospheric Organic Matter Using 
Ultrahigh-Resolution FT-ICR Mass Spectrometry, Environ. Sci. Technol., 46, 4312-4322, doi:10.1021/es203509b, 2012.

Lin, Y.-H., Zhang, Z., Docherty, K. S., Zhang, H., Budisulistiorini, S. H., Rubitschun, C. L., Shaw, S. L., Knipping, E. M., Edgerton, E. S., Kleindienst, T. E., Gold, A., and Surratt, J. D.: Isoprene Epoxydiols as Precursors to Secondary Organic Aerosol Formation: Acid-Catalyzed Reactive Uptake Studies with Authentic Compounds, Environ. Sci. Technol., 46, 250258, doi:10.1021/es202554c, 2012.

Lin, Y.-H., Zhang, H., Pye, H. O. T., Zhang, Z., Marth, W. J., Park, S., Arashiro, M., Cui, T., Budisulistiorini, S. H., Sexton, K. G., Vizuete, W., Xie, Y., Luecken, D. J., Piletic, I. R., Edney, E. O., Bartolotti, L. J., Gold, A., and Surratt, J. D.: Epoxide as a precursor to secondary organic aerosol formation from isoprene photooxidation in the presence of nitrogen oxides, Proc. Natl. Acad. Sci., 110, 6718-6723, doi:10.1073/pnas.1221150110, 2013.

Martin, S. T., Andreae, M. O., Althausen, D., Artaxo, P., Baars, H., Borrmann, S., Chen, Q., Farmer, D. K., Guenther, A., Gunthe, S. S., Jimenez, J. L., Karl, T., Longo, K., Manzi, A., Muller, T., Pauliquevis, T., Petters, M. D., Prenni, A. J., Poschl, U., Rizzo, L. V., Schneider, J., Smith, J. N., Swietlicki, E., Tota, J., Wang, J., Wiedensohler, A., and Zorn, S. R.: An overview of the Amazonian Aerosol Characterization Experiment 2008 (AMAZE08), Atmos. Chem. Phys., 10, 11415-11438, doi:10.5194/acp10-11415-2010, 2010.

Nizkorodov, S. A., Laskin, J., and Laskin, A.: Molecular chemistry of organic aerosols through the application of high resolution mass spectrometry, Phys. Chem. Chem. Phys., 13, 3612-3629, doi:10.1039/c0cp02032j, 2011.

Nozière, B., Ekström, S., Alsberg, T., and Holmström, S.: Radical-initiated formation of organosulfates and surfactants in atmospheric aerosols, Geophys. Res. Lett., 37, L05806, doi:10.1029/2009g1041683, 2010.

Redelsperger, J. L., Thorncroft, C. D., Diedhiou, A., Lebel, T., Parker, D. J., and Polcher, J.: African monsoon multidisciplinary analysis -An international research project and field campaign, Bull. Amer. Meteorol. Soc., 87, 1739-1746, doi:10.1175/bams87-12-1739, 2006.

Reinhardt, A., Emmenegger, C., Gerrits, B., Panse, C., Dommen, J., Baltensperger, U., Zenobi, R., and Kalberer, M.: Ultrahigh mass resolution and accurate mass measurements as a tool to characterize oligomers in secondary organic aerosols, Anal. Chem., 79, 4074-4082, doi:10.1021/ac062425v, 2007.

Robinson, N. H., Hamilton, J. F., Allan, J. D., Langford, B., Oram, D. E., Chen, Q., Docherty, K., Farmer, D. K., Jimenez, J. L., Ward, M. W., Hewitt, C. N., Barley, M. H., Jenkin, M. E., Rickard, A. R., Martin, S. T., McFiggans, G., and Coe, H.: Evidence for a significant proportion of Secondary Organic Aerosol from isoprene above a maritime tropical forest, Atmos. Chem. Phys., 11, 1039-1050, doi:10.5194/acp-11-1039-2011, 2011a.

Robinson, N. H., Newton, H. M., Allan, J. D., Irwin, M., Hamilton, J. F., Flynn, M., Bower, K. N., Williams, P. I., Mills, G., Reeves, C. E., McFiggans, G., and Coe, H.: Source attribution of Bornean air masses by back trajectory analysis during the OP3 project, Atmos. Chem. Phys., 11, 9605-9630, doi:10.5194/acp-11-96052011, 2011 b.

Saranjampour, P., Samburova, V., Hallar, A. G., Lowenthal, D., Zielinska, B., and Mazzoleni, L. R.: Ultrahigh-resolution FTICR mass spectrometric identification of water-soluble AOM in nonurban organic aerosols, Abstr. Pap. Am. Chem. Soc., 242, 313-ENVR, 2011.

Schindelka, J., Iinuma, Y., Hoffmann, D., and Herrmann, H.: Sulfate radical-initiated formation of isoprene-derived organosulfates in atmospheric aerosols, Faraday Discuss., doi:10.1039/c3fd00042g, 2013.

Shalamzari, M. S., Ryabtsova, O., Kahnt, A., Vermeylen, R., Herent, M.-F., Quetin-Leclercq, J., Van der Veken, P., Maenhaut, W., and Claeys, M.: Mass spectrometric characterization of organosulfates related to secondary organic aerosol from isoprene, Rapid Comm. Mass Spectrom., 27, 784-794, doi:10.1002/rcm.6511, 2013.

Surratt, J. D., Kroll, J. H., Kleindienst, T. E., Edney, E. O., Claeys, M., Sorooshian, A., Ng, N. L., Offenberg, J. H., Lewandowski, M., Jaoui, M., Flagan, R. C., and Seinfeld, J. H.: Evidence for organosulfates in secondary organic aerosol, Environ. Sci.Technol., 41, 517-527, doi:10.1021/es062081q, 2007.

Surratt, J. D., Gomez-Gonzalez, Y., Chan, A. W. H., Vermeylen, R., Shahgholi, M., Kleindienst, T. E., Edney, E. O., Offenberg, J. H., Lewandowski, M., Jaoui, M., Maenhaut, W., Claeys, M., Flagan, R. C., and Seinfeld, J. H.: Organosulfate formation in biogenic secondary organic aerosol, J. Phys. Chem. A, 112, 8345-8378, doi:10.1021/jp802310p, 2008.

Surratt, J. D., Chan, A. W. H., Eddingsaas, N. C., Chan, M., Loza, C. L., Kwan, A. J., Hersey, S. P., Flagan, R. C., Wennberg, P. O., and Seinfeld, J. H.: Reactive intermediates revealed in secondary organic aerosol formation from isoprene, Proc. Natl. Acad. Sci. USA, 107, 6640-6645, doi:10.1073/pnas.0911114107, 2010.

Tangki, H. and Chappell, N. A.: Biomass variation across selectively logged forest within a $225-\mathrm{km}(2)$ region of Borneo and its prediction by Landsat TM, For. Ecol. Manage., 256, 1960-1970, doi:10.1016/j.foreco.2008.07.018, 2008.

Wang, W., Wu, M. H., Li, L., Zhang, T., Liu, X. D., Feng, J. L., Li, H. J., Wang, Y. J., Sheng, G. Y., Claeys, M., and Fu, J. M.: Polar organic tracers in $\mathrm{PM}_{2.5}$ aerosols from forests in eastern China, Atmos. Chem. Phys., 8, 7507-7518, doi:10.5194/acp-87507-2008, 2008.

Warscheid, B., and Hoffmann, T.: Direct analysis of highly oxidised organic aerosol constituents by on-line ion trap mass spectrometry in the negative-ion mode, Rapid Communications in Mass Spectrometry, 16, 496-504, doi:10.1002/rcm.602, 2002.

Whitmore, T. C.: Tropical rain forests of the far-east 2 nd edition, Whitmore, T. C. Tropical Rain Forests of the Far East, 2nd Edition. XVI, 352 pp., Oxford University Press: New York, N.Y., USA; Clarendon Press: Oxford, England, Illus. Maps, XVI + 352P, 1984

Yasmeen, F., Vermeylen, R., Szmigielski, R., Iinuma, Y., Boege, O., Herrmann, H., Maenhaut, W., and Claeys, M.: Terpenylic acid and related compounds: precursors for dimers in secondary organic aerosol from the ozonolysis of alpha- and beta-pinene, Atmos. Chem. Phys., 10, 9383-9392, doi:10.5194/acp-10-93832010, 2010.

Yasmeen, F., Szmigielski, R., Vermeylen, R., Gomez-Gonzalez, Y., Surratt, J. D., Chan, A. W. H., Seinfeld, J. H., Maenhaut, W., and Claeys, M.: Mass spectrometric characterization of isomeric terpenoic acids from the oxidation of alpha-pinene, beta-pinene, d-limonene, and Delta(3)-carene in fine forest aerosol, J. Mass Spectrom., 46, 425-442, doi:10.1002/jms.1911, 2011. 